\title{
Mode of action of lactocin 160, a bacteriocin from vaginal Lactobacillus rhamnosus
}

\author{
JIE LI $^{1}$, ALLA A. AROUTCHEVA ${ }^{2,4}$, SEBASTIAN FARO ${ }^{2,3}, \&$ MICHAEL L. CHIKINDAS ${ }^{1,4}$ \\ ${ }^{1}$ Rutgers, The State University of New fersey, New Brunswick, NF, USA ${ }^{2}$ Rush University Medical Center, Chicago, IL, \\ USA ${ }^{3}$ The Woman's Hospital of Texas, Houston, TX, USA ${ }^{4}$ Health Promoting Naturals (HEPNA) Inc., Highlands Park, \\ $N F, U S A$
}

\begin{abstract}
Objectives. To determine the mechanism of antimicrobial action of lactocin 160, a bacteriocin produced by the healthy vaginal strain of Lactobacillus rhamnosus, using an established model, with Micrococcus luteus ATCC 10420 as a test organism. Methods. Sensitivity of M. luteus to lactocin 160 was determined by the diffusion assay. Loss of cellular ATP in the lactocintreated cells was elucidated using a commercially available ATP determination kit (luciferin-luciferase bioluminescence assay). Luminescence intensity as a reflection of ATP quantity was determined using a luminometer. Dissipation of membrane potential $(\Delta \psi)$ was studied using fluorophore DiSC3(5) with the fluorescence spectrum sensitive to changes in $\Delta \psi$. Results. Lactocin 160 inhibited growth of M. luteus ATCC 10420 at a concentration of $5 \mu \mathrm{g} / \mathrm{ml}$. There were no significant changes in the intracellular ATP level of $M$. luteus upon the addition of $20 \mu \mathrm{g} / \mathrm{ml}$ of lactocin 160 . However, the extracellular ATP level increased significantly. This means that the treatment of cells with lactocin 160 resulted in an efflux of ATP from inside the cells. Therefore, a partially purified lactocin 160 preparation $(16 \mu \mathrm{g} / \mathrm{ml}$ of the bacteriocin in the sample) killed sensitive cells and dissipated $3.12 \pm 0.36 \%$ of $\Delta \psi$.

Conclusion. Lactocin 160 has a mode of action typical for bacteriocins. It disturbs the cellular membrane $(\Delta \psi$ dissipation) and induces ATP efflux, most likely because of the pore formation, which is a common mechanism of action for many bacteriocins.
\end{abstract}

Keywords: Lactobacillus, bacteriocin, ATP, membrane potential

\section{Introduction}

Bacterial vaginosis (BV) is a vaginal, multi-microbial syndrome that can be a risk factor for human immunodeficiency virus (HIV) transmission and acquisition. Several cross-sectional studies identify $\mathrm{BV}$ as a cofactor in the sexual transmission of HIV [1-3]. Major BV organisms directly up-regulate HIV replication [4-6]. Our in vitro data indicated that the most frequent BV-associated microorganisms Gardnerella vaginalis, Peptostreptococcus spp and Prevotella bivia stimulate the expression of HIV $[5,7]$.

Lactobacilli in the lower genital tract of healthy females protect the vagina from the invasion of pathogens by producing antimicrobial substances, such as weak organic acids (mostly lactic acid), bacteriocins and hydrogen peroxide [8-10]. Bacter- iocins are defined as proteinaceous substances that exhibit antibacterial activity. Vaginal lactobacilli produce bacteriocins effective against vaginal pathogens such as Enterococcus spp and Neisseria gonorrhoeae [11], and may have a fungistatic effect on Candida albicans [12]. Among 22 vaginal Lactobacillus strains studied by Aroutcheva et al. $[9,13]$, $77.3 \%$ exhibited antimicrobial activity against $G$. vaginalis. One of these strains, designated Lactobacillus rhamnosus 160 , produces a bacteriocin named lactocin 160 that inhibits growth of $G$. vaginalis [13].

Here we report for the first time, our preliminary data on the mechanism of antimicrobial action for the bacteriocin produced by the vaginal strain of Lactobacillus, lactocin 160, using a well-established model where Micrococcus luteus ATCC 10420 is a test organism [14].

Correspondence: Michael L. Chikindas, Department of Food Science, Cook College, Rutgers, The State University of New Jersey, 65 Dudley Road, New Brunswick, NJ 08901-8520, USA. Tel: 7329329611 ext 218. Fax: 732932 6776. E-mail: tchikindas@aesop.rutgers.edu 


\section{Materials and methods}

\section{Lactocin 160 purification}

The bacteriocin producer L. rhamnosus 160 was isolated from a patient with healthy vaginal microflora. Lactocin 160 was purified following the previously described procedure [15]. Briefly, $2000 \mathrm{ml}$ of the overnight culture of L. rhamnosus 160 grown in MRS broth (Remel, KS) anaerobically at $36^{\circ} \mathrm{C}$, were concentrated by centrifugation (7000 x $g$, $20 \mathrm{~min}$ at $5^{\circ} \mathrm{C}$ ), washed three times in $1 \times$ PBS (pH 6.0) and transferred into $200 \mathrm{ml}$ of chemically defined media (CDM) composed from substances found in vaginal secretion but without any proteins and amino acids [16]. The cells were incubated anaerobically at $37^{\circ} \mathrm{C}$ for $18 \mathrm{~h}$ with constant shaking and then removed by centrifugation at $12,000 \times \mathrm{g}$ for $25 \mathrm{~min}$ at $5^{\circ} \mathrm{C}$.

The non-lactocin 160 proteins were precipitated from the CDM by $80 \%$ ammonium sulfate for $3 \mathrm{~h}$ at $5^{\circ} \mathrm{C}$. The precipitate was removed by centrifugation at $12,000 \times \mathrm{g}$ for $25 \mathrm{~min}$ at $5^{\circ} \mathrm{C}$. The supernatant containing lactocin 160 was dialyzed against deionized water, using a dialysis bag with MW CO 500 (Spectrum, CA), within 3 days. The dialyzed preparations were concentrated by lyophilization.

The 10-20\% pre-cast sodium dodecyl sulfate (SDS) polyacrilamide gel (Bio-Rad, CA) electrophoresis (SDS-PAGE) was conducted to determine the presence of lactocin 160 in the sample. The SDSPAGE was conducted according to the Bio-Rad manual at $200 \mathrm{~V}$ for $90 \mathrm{~min}$. To visualize proteins, the gel was stained with a Bio-Rad Silver Stain according to the manufacturer's instructions.

\section{Nisin preparation}

Nisin powder, purified bacteriocin produced by Lactococcus lactis, was a gift from Aplin \& Barrett (Beaminster, UK). Nisin is the only lactic acid bacteria-produced bacteriocin that is used for food preservation in more than fifty countries. Because it is a class Ia bacteriocin from Lactococcus lactis, with a well-studied mechanism of action, nisin was used as a positive control [17].

A high concentration of nisin solution can only be obtained at a low $\mathrm{pH}$ since this bacteriocin has the best solubility in the $\mathrm{pH}$ range of $1.7-3.5$. To prepare a highly concentrated nisin stock solution, one gram of dry preparation of the bacteriocin was dissolved in $1 \mathrm{ml}$ of commonly used "nisin diluent" consisting of $0.02 \mathrm{~N} \mathrm{HCl}$ ( $\mathrm{pH}$ 1.7). The stock solution was used to prepare working concentrations in the PBS buffer (pH 7.2). Because of the high buffer capacity of the PBS and the small amounts of nisin in final preparations, the $\mathrm{pH}$ of nisin working solutions was approximately 7.0 .

\section{Well diffusion assay}

The stock culture of Micrococcus luteus ATCC 10420 used in this study was stored in a nutrient broth (Difco, MI) with $20 \%$ glycerol at $-70^{\circ} \mathrm{C}$. The strain was streaked on a fresh nutrient agar (Difco, MI) plate three times before it was used as working culture, which was kept at $4{ }^{\circ} \mathrm{C}$. The CDM was used as a negative control. To conduct the susceptibility test, a partially purified preparation of lactocin 160 was dissolved in PBS ( $\mathrm{pH} 7.2$ ) at $20 \mathrm{mg} / \mathrm{ml}$.

Before pouring plates, M. luteus ATCC 10420 cells were seeded into the nutrient agar to make a final concentration of approximately $10^{4} \mathrm{CFU} / \mathrm{ml}$. When the agar was polymerized in the Petri dishes, wells $6 \mathrm{~mm}$ in diameter were punctured in the agar. Then $80 \mu \mathrm{l}$ of the 2-fold dilutions of lactocin 160 preparation was added into the wells. The agar plates were pre-incubated at $4{ }^{\circ} \mathrm{C}$ for $6 \mathrm{~h}$, so the bacteriocins could diffuse into the agar, followed by $24 \mathrm{~h}$ of incubation at $30^{\circ} \mathrm{C}$. The observed inhibition zones indicated activity of the bacteriocins.

\section{Protein assay}

To determine protein (the bacteriocin) concentration in the partially purified preparation of lactocin 160, the RC DC ${ }^{\mathrm{TM}}$ Protein Assay kit (BioRad) was used according to the manufacturer's manual.

\section{ATP assay}

First, an ATP standard curve was obtained by following the procedure described in the manual (Technical Bulletin No. BAAB-1) included with the ATP bioluminescent assay kit (FL-AA, SigmaAldrich Corporation, St. Louis, MO). The total ATP level of both the normal and stressed cells was determined as described previously [18]. Briefly, $1 \mathrm{ml}$ of $M$. luteus ATCC 10420 was collected by centrifugation, and the pellet was resuspended in a $50 \mathrm{mM}$ MES (2-[N-Morpholino]ethanesulfonic acid) buffer ( $\mathrm{pH}$ 6.5) supplemented with $0.2 \%$ glucose and $10 \mathrm{mM} \mathrm{KCl}$ to energize the cells. The cell suspension was divided into 2 aliquots. One aliquot was treated with lactocin 160, and the other (no bacteriocin added) served as the control. After $10 \mathrm{~min}$ of energization with glucose, the $10 \mathrm{mg} / \mathrm{ml}$ (final concentration) lactocin 160 partially purified preparation was added in one aliquot of cell suspension. At the same time, the same volume of the MES buffer was added to the control cells. For both cells with and without lactocin 160 treatment, the procedures were the same. To determine the total ATP level, at predetermined intervals, $20 \mu \mathrm{l}$ of the cell suspension 
was quickly added to $80 \mu \mathrm{l}$ DMSO (dimethyl sulfoxide, Fischer Biotech, NJ) and mixed for $30 \mathrm{~s}$ before dilution with $4.9 \mathrm{ml}$ of cold water $\left(4^{\circ} \mathrm{C}\right)$. To measure the extracellular ATP level, $20 \mu \mathrm{l}$ of the same cell suspension was mixed with $80 \mu \mathrm{l} \mathrm{H}_{2} \mathrm{O}$ instead of DMSO. The subsequent steps were the same as those for the total ATP determination. The $100 \mu \mathrm{l}$ of the cells in DMSO or cells in $\mathrm{H}_{2} \mathrm{O}$ was added to the $100 \mu \mathrm{l}$ ATP assay enzyme solution (containing luciferase, luciferin, $\mathrm{MgSO}_{4}, \mathrm{DTT}$, EDTA BSA and Tricine buffer salt) (1:25 dilution of stock) and incubated. Relative luminescence intensity (RLI) was determined instantly using a luminometer (Thermo Labsystem, Franklin, MA). RLI data were converted into ATP concentration using the ATP standard curve constructed earlier. The intracellular ATP level was calculated by subtracting the extracellular ATP level from the total ATP level.

\section{Membrane potential $(\Delta \psi)$ dissipation}

The mid-log phase M. luteus culture was collected by centrifugation and re-suspended in $50 \mathrm{mM}$ HEPES ( $\mathrm{pH}$ 7.0). The cells were washed twice in the buffer before they were re-suspended in the buffer, which was ten times smaller in volume, to achieve $\mathrm{OD}_{600}=40$. Fluorescence measurements were performed in a PerkinElmer LS-50B spectrofluorometer (PerkinElmer Life and Analytical Sciences, Inc., Boston, MA). Parameters were set up as: excitation $=643 \mathrm{~nm}$; emission $=666 \mathrm{~nm}$; and slit width $=10 \mathrm{~nm}$ for both. For each measurement, $5 \mu 1$ of $2 \mathrm{mM}$ DiSC3 were added to a $2 \mathrm{ml}$ $50 \mathrm{mM}$ K-HEPES buffer ( $\mathrm{pH}$ 7.0) to reach a final concentration of $5 \mu \mathrm{M}$. After stabilization of the baseline, $20 \mu \mathrm{l}$ cells were added (final $\mathrm{OD}_{600}$ was $\sim 0.3$ ) followed by $20 \mu \mathrm{l} 20 \%$ glucose to energize the cells. Then $2 \mu \mathrm{l}$ of $5 \mathrm{mM}$ nigericin (final concentration of $5 \mu \mathrm{M}$ ) were added to convert the $\mathrm{pH}$ gradient. Different amounts of either nisin or lactocin were used to deplete $\Delta \psi$ after signal stabilization. Finally, $20 \mu \mathrm{l} 0.3 \mathrm{mM}$ valinomycin (final concentration of $3 \mu \mathrm{M}$ ) were added to observe complete dissipation of the $\Delta \psi$. The increase in the fluorescence intensity induced by different bacteriocins or different concentrations of the same bacteriocin was compared. Fluorescence intensity after the addition of nigericin was denoted as $\mathrm{I}_{0}$. Intensity following the addition of any bacteriocin was denoted as $I_{t}$ and intensity after valinomycin-induced total depletion of membrane potential was $\mathrm{I} \infty$. Therefore, the $\Delta \psi$ dissipation percentage (\%) can be calculated as

$$
\Delta \psi \text { dissipation } \%=\left(\mathrm{I}_{\mathrm{t}}-\mathrm{I}_{0}\right) /\left(\mathrm{I} \infty-\mathrm{I}_{0}\right) \times 100
$$

\section{Statistical analysis}

The variance of the data between the replicates was less than $10 \%$. Standard deviation was calculated for each cell population studied.

\section{Results}

Using the method developed in our laboratory, we isolated the antibacterial peptide with the molecular weight of $3.8 \mathrm{kDa}$ (Figure 1). According to the SDS-PAGE, lactocin 160 was the only protein present in the preparation. However in addition to the peptide, the lactocin 160 partially purified preparation contained CDM components and possibly metabolic products of a non-proteinaceous nature.

The minimum inhibitory concentration (MIC) of the lactocin 160 partially purified preparation against $M$. luteus ATCC 10420 was $5 \mu \mathrm{g} / \mathrm{ml}$. CDM had no effect on the growth of the tested microorganism.

There were no significant changes in the intracellular ATP level of $M$. luteus upon the addition of $20 \mu \mathrm{g} / \mathrm{ml}$ of lactocin 160 (partially purified preparation of $20 \mathrm{mg} / \mathrm{ml}$ of total sample, data not shown). At the same time, the extracellular ATP level increased

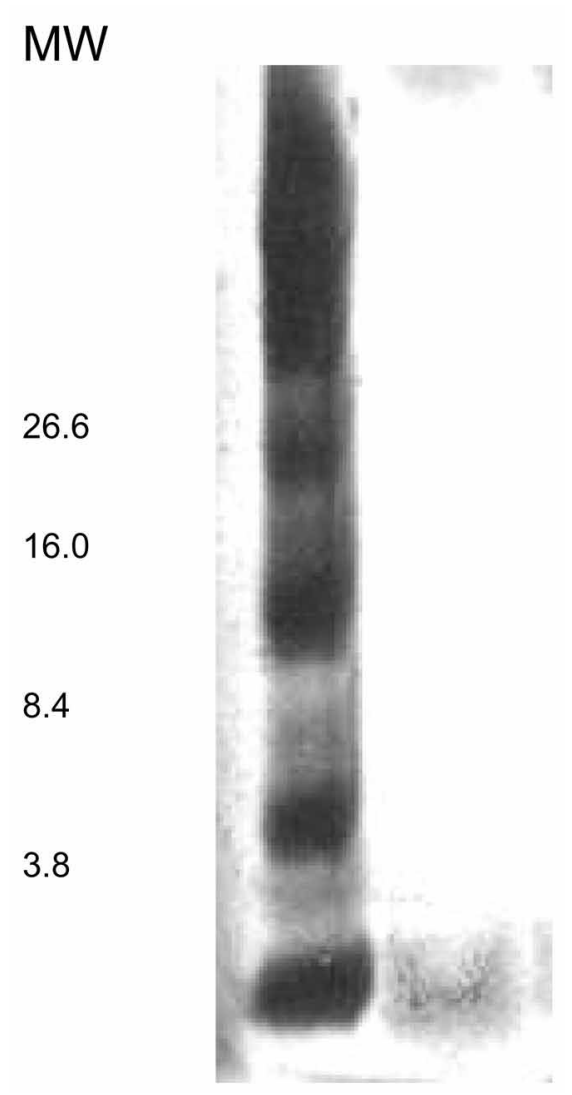

Figure 1. Lactocin 160, MW $3.8 \mathrm{kDa}$. 
significantly (Figure 2). This means that treatment of the cells with lactocin 160 resulted in an efflux of ATP from inside of the cells.

As shown in Table I, $8.0 \mathrm{mg} / \mathrm{ml}$ of partially purified lactocin 160 preparation $(16 \mu \mathrm{g} / \mathrm{ml}$ of the bacteriocin in the sample) dissipated $3.12 \pm 0.36 \%$ of $\Delta \psi$.

\section{Discussion}

Bacteriocins exhibit inhibitory effects against various pathogens in a manner similar to antibiotics. However, bacteriocins are distinguished from antibiotics on the basis of their synthesis, mode of action, toxicity and resistance mechanisms $[15,16]$. Organisms resistant to antibiotics are generally not cross-resistant with bacteriocins, and bacteriocin resistance is not always genetically determined [17].

Bacteriocins kill sensitive cells by depleting the transmembrane potential $(\Delta \psi)$ and/or the $\mathrm{pH}$ gradient and forming pores in the membrane, resulting in the leakage of cellular materials [18].

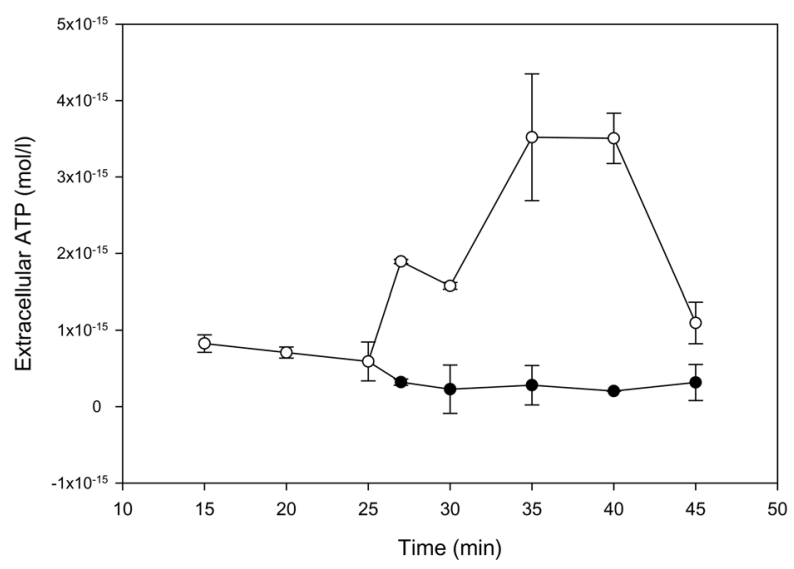

Figure 2. Influence of lactocin 160 on extracellular ATP levels in M. luteus ATCC 10420. The changes in extracellular ATP level induced by lactocin 160 (open circles) were compared with ATP level in non-treated cells (closed circles).

Table I. Dissipation of $\Delta \psi$ in M. luteus ATCC 10420 by lactocin 160.

Amount of partially purified lactocin 160 preparation Total sample $\mathrm{mg} / \mathrm{ml} \quad$ Total protein $\mu \mathrm{g} / \mathrm{ml} \quad \Delta \psi$ dissipation $\%$

\begin{tabular}{lcc}
\hline 0.4 & 0.8 & 0 \\
2.0 & 4 & $1.83 \pm 0.27$ \\
8.0 & 16 & $3.12 \pm 0.36$ \\
Pure nisin (control) $\mu \mathrm{g} / \mathrm{ml}$ & \\
1 & $3.66 \pm 0.45$ & \\
5 & $18.18 \pm 3.10$ & \\
10 & $42.35 \pm 5.27$ & \\
\hline
\end{tabular}

Electrostatic interactions with negatively charged phosphate groups on target cell membranes contribute to the initial binding of many bacteriocins to the sensitive cell's membrane $[19,20]$. Other factors, such as the phospholipid composition of the target bacterial membrane and the environmental $\mathrm{pH}$, influence the bacteriocin's activity [19].

In this study we elucidated the general mechanism of action of partially purified lactocin 160 from vaginal L. rhamnosus against $M$. luteus ATCC 10420. We intentionally studied the peptide in its partially purified form, which contains a trace of media components. Lactocin 160 is normally secreted from the strain into the vaginal environment. We speculate that the CDM, which mimics vaginal fluid, may also stabilize and protect the peptide from degradation. Therefore, it should be present in lactocin 160 topical vaginal microbicide formulation.

It was shown that lactocin 160 disturbs the cellular membrane and induces ATP efflux. Bacteriocins are known to deplete intracellular ATP as a result of pore formation [17]. Dissipation of $\Delta \psi$ is a typical characteristic of the pore-forming bacteriocin as it indicates the disturbance of the membrane's integrity by the bacteriocin molecules. In this study, we found that lactocin 160 dissipates the membrane potential of sensitive cells. Thus, dissipation of membrane potential is only part of the mode of action of lactocin 160. In addition, lactocin 160 did not affect the membrane $\mathrm{pH}$ gradient $(\Delta \mathrm{pH})$ of $M$. luteus (data not shown). This was not a surprise since some bacteriocins selectively dissipate one component of the proton motive force. Bacteriocins, such as lactococcin G and lactocin 3147 were reported to induce pores selective for $\mathrm{K}^{+}$ions and inorganic phosphate [2124]. Enterocin P caused a significant reduction of membrane potential $(\Delta \psi)$ and the intracellular pool of ATP from Enterococcus faecium T136. However, the $\Delta \mathrm{pH}$ was not affected in the cells of $E$. faecium treated with enterocin $\mathrm{P}$ [21]. Therefore in addition to the membrane potential dissipation, there must be some other mechanism(s) that contribute(s) to the antimicrobial action of lactocin 160 observed in the well-diffusion assay.

Using the commonly accepted method for testing bacteriocin activity, with $M$. luteus ATCC 10420 as the test strain, we showed that a partially purified preparation of lactocin 160 has a mode of action typical for bacteriocins. The antimicrobial activity of this partially purified lactocin 160 preparation was somewhat low for $M$. luteus ATCC 10420. This is because this preparation is likely to contain media components of a non-proteinaceous nature and metabolic products that were not removed by the partial purification. Therefore we 
assume that the lactocin 160, purified to homogeneity, will have a much higher activity suitable for application. However, the goal of this research was not to purify lactocin 160 to homogeneity but to obtain, for the first time, preliminary data on the possible mechanism of action of lactocin 160 isolated from a vaginal specimen dominated by Lactobacillus. The preliminary mode of action study was performed using the strain of $M$. luteus that is commonly accepted as a reference bacteriocinsensitive organism. However, it is not the most lactocin 160-sensitive strain and it is not a vaginal isolate. In fact, vaginal pathogens are more sensitive to lactocin 160 than M. luteus (personal communication). In addition commercially available topical antimicrobials, such as $2 \%$ cleocin and $0.75 \%$ metrogel that are usually prescribed for the treatment of bacterial vaginosis and other vaginitis, release $100 \mathrm{mg}$ of clindamycin (single dose) and $37.5 \mathrm{mg}$ of metronidazole. These very high concentrations of antimicrobials kill not only BVassociated bacteria but also healthy vaginal lactobacilli $[25,26]$. At the same time, our partially purified preparation of lactocin 160 kills BVassociated microorganisms but does not kill healthy vaginal microflora, therefore it is specific in its antimicrobial action (personal communication).

The rapidly increasing prevalence of genital pathogens resistant to conventional antibiotics has prompted a search for new therapeutic agents. An antibacterial peptide produced by vaginal lactobacilli and having a mechanism of action different from conventional antibiotics can be a good choice for the replacement of antibiotics in the prophylaxis of BV. Further study of lactocin 160s mechanism of action will be performed using $G$. vaginalis as a major BVassociated microorganism and purified to homogeneity preparation of the bacteriocin.

\section{References}

1. Cohen CR, Duerr A, Pruithithada N, Rugpao S, Hillier S, Garcia P, Nelson K. Bacterial vaginosis and HIV seroprevalence among female commercial sex workers in Chiang Mai, Thailand. AIDS 1995;9:1093-1097.

2. Schmid G, Markowitz L, Joesoef R, Koumans E. Bacterial vaginosis and HIV infection. Sex Transm Infect 2000;76:3-4.

3. Taha TE, Hoover DR, Dallabetta GA, Kumwenda NI, Mtimavalye LA, Yang LP, Liomba GN, Broadhead RL, Chiphangwi JD, Miotti PG. Bacterial vaginosis and disturbances of vaginal flora: association with increased acquisition of HIV. AIDS 1998;12:1699-1706.

4. Al-Harthi L, Roebuck KA, Olinger GG, Landay A, Sha BE, Hashemi FB, Spear GT. Bacterial vaginosis-associated microflora isolated from the female genital tract activates HIV-1 expression. J Acquir Immune Defic Syndr 1999;21: 194-202.
5. Hashemi FB, Ghassemi M, Faro S, Aroutcheva A, Spear GT. Induction of human immunodeficiency virus type 1 expression by anaerobes associated with bacterial vaginosis. J Infect Dis 2000; $181: 1574-1580$.

6. Hillier SL. The vaginal microbial ecosystem and resistance to HIV. AIDS Res Hum Retroviruses. 1998;14(Suppl 1):S17S21.

7. Simoes JA, Hashemi FB, Aroutcheva AA, Heimler I, Spear GT, Shott S, Faro S. Human immunodeficiency virus type 1 stimulatory activity by Gardnerella vaginalis: relationship to biotypes and other pathogenic characteristics. J Infect Dis 2001;184:22-27.

8. Antonio MA, Hawes SE, Hillier SL. The identification of vaginal Lactobacillus species and the demographic and microbiologic characteristics of women colonized by these species. J Infect Dis 1999;180:1950-1956.

9. Aroutcheva A, Gariti D, Simon M, Shott S, Faro J, Gurguis A, Faro S. Defense factors of vaginal lactobacilli. Am J Obstet Gynecol 3001;185:375-379.

10. Boris S, Barbes C. Role played by lactobacilli in controlling the population of vaginal pathogens. Microbes Infect 2000;2:543-546.

11. Juarez Tomas MS, Bru E, Wiese B, de Ruiz Holgado AA, Nader-Macias ME. Influence of $\mathrm{pH}$, temperature and culture media on the growth and bacteriocin production by vaginal Lactobacillus salivarius CRL 1328. J Appl Microbiol 2002;93: 714-724.

12. Okkers DJ, Dicks LM, Silvester M, Joubert JJ, Odendaal HJ. Characterization of pentocin TV35b, a bacteriocin-like peptide isolated from Lactobacillus pentosus with a fungistatic effect on Candida albicans. J Appl Microbiol 1999;87:726-734.

13. Aroutcheva A, Simoes J, Faro S. Antimicrobial protein produced by vaginal Lactobacillus acidophilus that inhibits Gardnerella vaginalis. Infect Dis Obstet Gynecol 2001;9:3340.

14. Dutreux N, Notermans S, Gongora-Nieto MM, BarbosaCanovas GV, Swanson BG. Effects of combined exposure of micrococcus luteus to nisin and pulsed electric fields. Int $\mathrm{J}$ Food Microbiol 2000;60:147-152.

15. Nes IF, Diep DB, Havarstein LS, Brurberg MB, Eijsink V, Holo, H. Biosynthesis of bacteriocins in lactic acid bacteria. Antonie van Leeuwenhoek 1996;70:113-128.

16. Nissen-Meyer J, Nes IF. Ribosomally synthesized antimicrobial peptides: their function, structure, biogenesis, and mechanism of action. Arch Microbiol 1997;167:67-77.

17. Cleveland J, Montville TJ, Nes IF, Chikindas ML. Bacteriocins: safe, natural antimicrobials for food preservation. Int J Food Microbiol 2001;71:1-420.

18. Chung HJ, Montville TJ, Chikindas ML. Nisin depletes ATP and proton motive force in mycobacteria. Lett Appl Microbiol 2000;31:416-420.

19. Chen Y, Ludescher RD, Montville TJ. Electrostatic interactions, but not the YGNGV consensus motif, govern the binding of pediocin PA-1 and its fragments to phospholipid vesicles. Appl Environ Microbiol 1997;63:4770-4777.

20. Lins L, Ducarme P, Breukink E, Brasseur R. Computational study of nisin interaction with model membrane. Biochim Biophysi Acta 1999;420:111-120.

21. Herranz C, Chen Y, Chung HJ, Cintas LM, Hernandez PE, Montville TJ, Chikindas ML. Enterocin P selectively dissipates the membrane potential of Enterococcus faecium T136. Appl Environ Microbiol 2001;67:1689-1692.

22. McAuliffe O, Ryan MP, Ross RP, Hill C, Breeuwer P, Abee T. Lacticin 3147, a broad-spectrum bacteriocin which selectively dissipates the membrane potential. Appl Environ Microbiol 1998;64:439-445. 
23. Moll G, Ubbink-Kok T, Hildeng-Hauge H, Nissen-Meyer J, Nes IF, Konings WN, Driessen JA. Lactococcin G is a potassium ion-conducting, two-component bacteriocin. $\mathrm{J}$ Bacteriol 1996;178:600-605.

24. Riley MA, Wertz JE. Bacteriocin diversity: ecological and evolutionary perspectives. Biochimie 2002;84:357-364.
25. Aroutcheva A, Simoes J, Shott S, Faro S. The inhibitory effect of clindamycin on lactobacillus in vitro. Infect Dis Obstet Gynecol 2001;9:239-242.

26. Simoes J, Aroutcheva A, Shott S, Faro S. Effect of Metronidazole on the growth of vaginal lactobacilli in vitro. Infect Dis Obstet Gynecol 2001;9:41-46. 


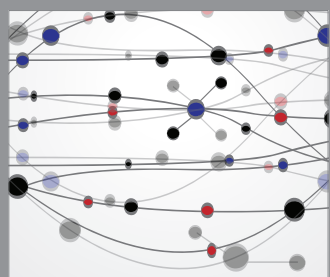

The Scientific World Journal
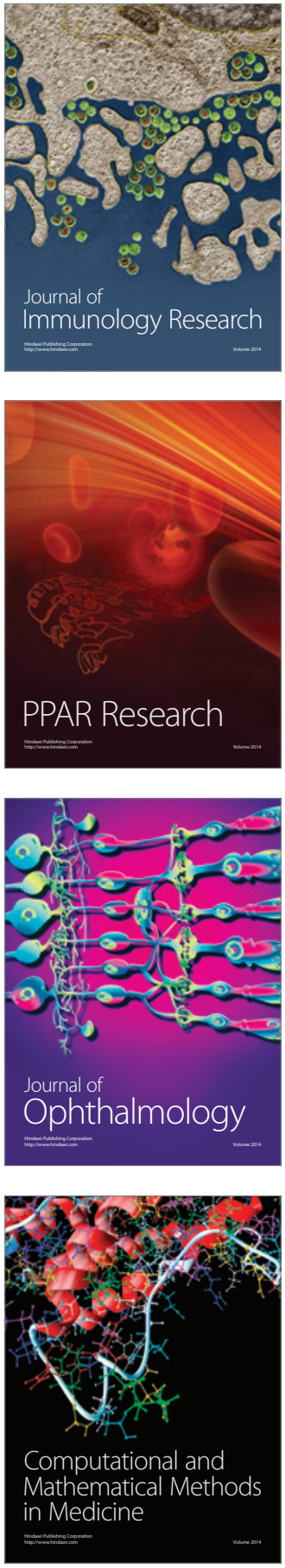

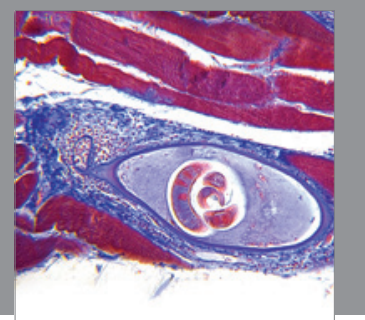

Gastroenterology

Research and Practice
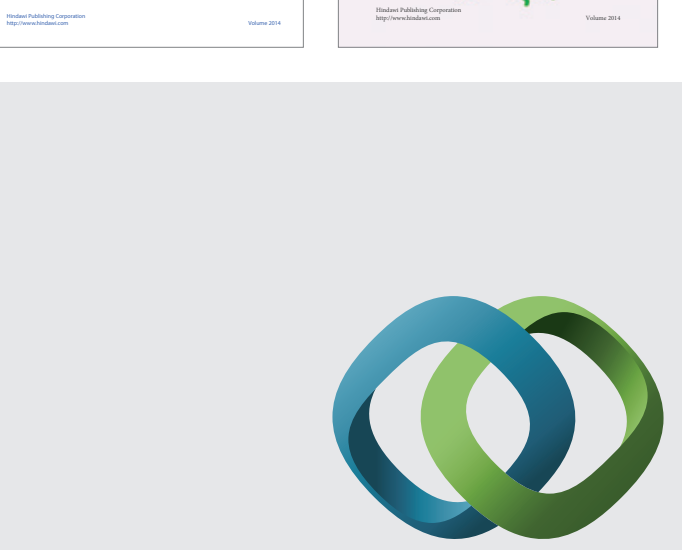

\section{Hindawi}

Submit your manuscripts at

http://www.hindawi.com
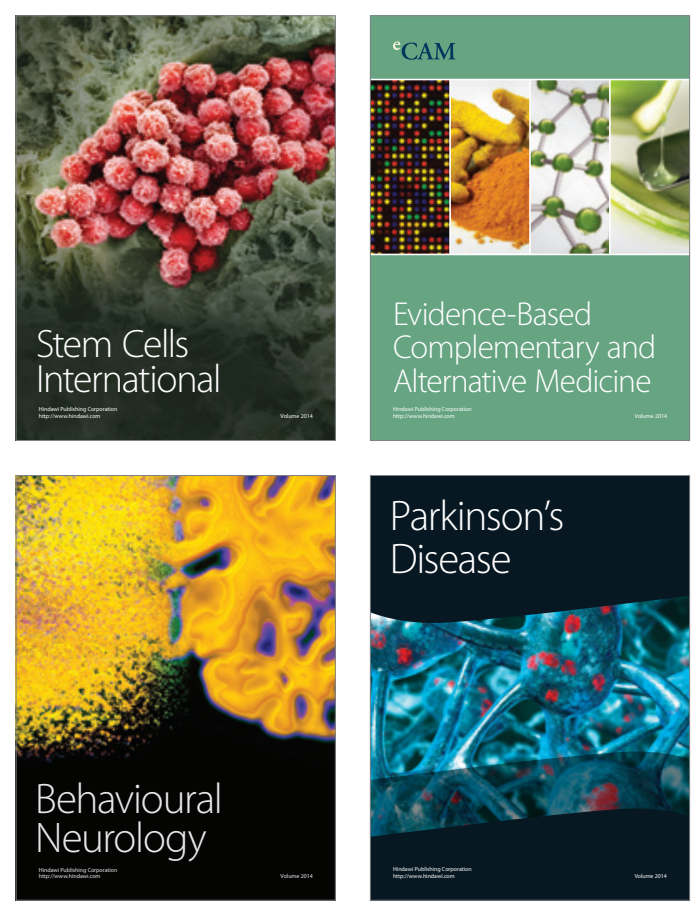

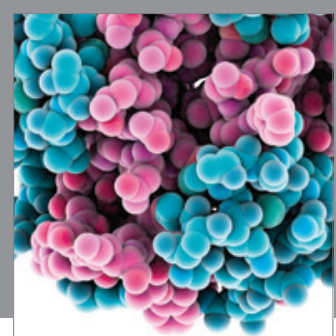

Journal of
Diabetes Research

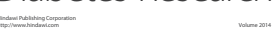

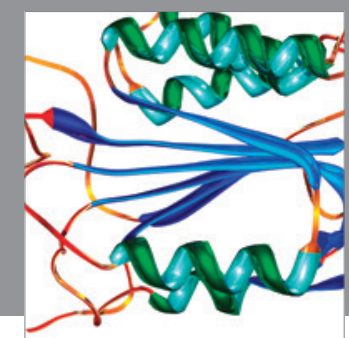

Disease Markers
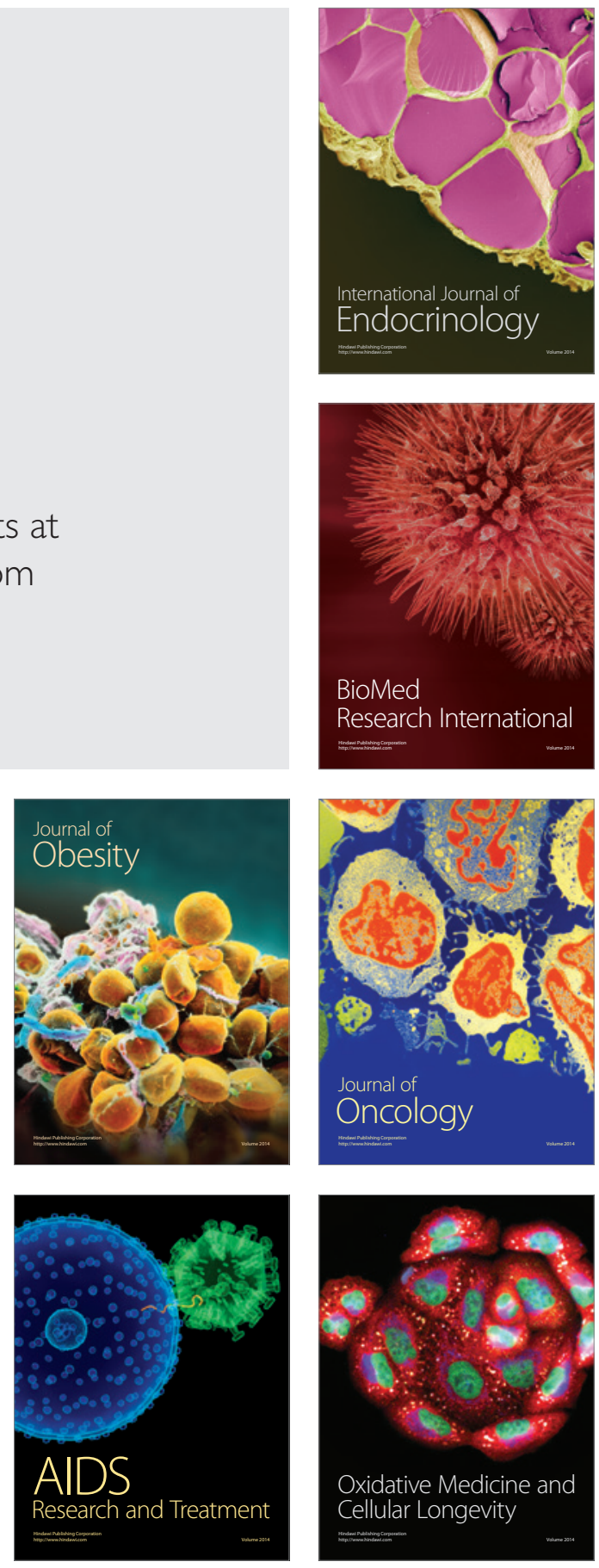